\title{
Building a corporate brand: The internal brand building process in Swedish service firms
}

Received (in revised form): |4th April, 2008

\begin{abstract}
ÅSA WALLSTRÖM
is Assistant Professor at Division of Industrial Marketing, e-Commerce and Logistics at Luleå University of Technology. She has a PhD in industrial marketing. Her research interests include service marketing, branding, industrial buying behaviour, e-Commerce and e-government.
\end{abstract}

\section{TED KARLSSON}

is Lecturer in Marketing at Division of Industrial Marketing, e-Commerce and Logistics at Luleå University of Technology. He holds a licentiate degree in industrial marketing. His research interest is branding and service marketing.

\section{ESMAIL SALEHI-SANGARI}

is Chair Professor and Head of Division of Industrial Marketing, e-Commerce and Logistics at Luleå University of Technology. His research is focused on industrial marketing, e-Commerce, SME's, branding and e-government. His articles have appeared in journals such as the European Journal of Marketing, Industrial Marketing Management, The Journal of Marketing Management and International Journal of Management.

\section{Keywords}

corporate brand;

brand-building process; brand audit; brand identity; service firm; Sweden
Åsa Wallström

Luleå University of Technology

Industrial Marketing and

e-Commerce

LULEÅ 971 87, Sweden

Tel: +49920491000

Fax: + 46920492355

E-mail: asa.wallstrom@Itu.se

\section{Abstract}

There is consensus that every organisation needs to develop a strong brand as part of its business strategy. It is, however, unclear how corporate brands can be effectively developed. The aim of this study is to empirically explore the internal corporate brand-building process in Swedish service firms. This process refers to activities that occur before the implementation of the brand. This is a qualitative study in which three case studies are presented and in which purposive sampling was applied. The study's aim was to find illustrative cases of firms that had recently conducted an internal, corporate brand-building process. The selected firms had initiated the process based on different circumstances (ie due to a crisis, geographical expansion or strategic repositioning). Personal interviews were used as the main data collection method. Three concurrent flows of activities, that is, data reduction, data display and conclusion drawing, have been applied in the data analysis. All firms aimed to strengthen the corporate brand in their brand portfolio by reducing sub-brands, and by updating their brand identity and brand position statements. Findings show that even though the three firms had initiated the internal corporate brand-building process for different reasons, the three stages in the process, that is, brand audit, brand identity and brand position statements, could still be identified. Differences, however, occurred within the stages. Journal of Brand Management (2008) 16, 40-50. doi:10.1057/bm.2008.18; published online 6 June 2008

\section{INTRODUCTION}

The brand is often mentioned as a firm's most valuable asset. This is especially true for the company brand, that is, the cor- porate brand. ${ }^{1}$ Corporate branding is identified as the way in which an organisation communicates its identity. ${ }^{2}$ Several authors stress that there is a move from 
product brands toward corporate brands in both practice and theory. ${ }^{3-7}$ Branding on the corporate level is challenging, since this calls for a company-wide approach. ${ }^{3}$ It is, however, still not clear how corporate brands can be effectively developed. ${ }^{2,5}$

Branding is the cornerstone of service marketing for the 21 st century, ${ }^{8}$ and service companies usually rely on the corporate brand. ${ }^{8-10}$ Service brands were long seen as less interesting than product brands. This, however, has changed and many of today's exciting brands have emerged from the service sector. ${ }^{11}$ The brand is even more important for service firms than for those that sell tangible products, due to the intangible characteristics of services. ${ }^{12}$ Corporate branding can enhance the perceived differentiation between competing service brands. ${ }^{13}$ Moreover, a strong orporate brand will guarantee quality and reduce the perceived risk associated with buying an intangible service. ${ }^{14}$ It will also help customers visualise and understand the service. ${ }^{8,15}$

With few exceptions, the corporate brand received little attention until 1995. Since corporate branding is a relatively new area, there is still a lack of research in this field. ${ }^{2,5,16}$ Corporate brands, however, have received increasing attention in the academic literature over the past decade. ${ }^{3-5,17-22}$ Still, a review of previous work in the area reveals that knowledge concerning corporate brands in service firms is limited.

There is consensus that an ongoing, systematic brand-building process is important for creating a strong brand. 3,9,16,21,23 A general criticism regarding the literature focusing on brand building, however, is that most of the research is conceptual and/or that there is a lack of empirical testing. 5, $9,24,25$ The branding literature is fragmented and lacks a model that describes brand building from the firm's perspective. ${ }^{9}$ Moreover, the literature provides elusive advice to managers with respect to developing a strong brand, even though there is a common understanding that a strong brand is needed. ${ }^{2}$ While empirical research would help companies build and manage their corporate brands, many organisations today are unsure of what they should do. Given these limitations, the aim of this study is to explore the internal corporate brand-building process in Swedish service firms.

The internal corporate brand-building process refers to the activities that occur before the actual implementation of the brand. Firms must decide how they want the brand's identity to be perceived, before it can be communicated internally and externally. The brand-building process will be studied from the firm's perspective, implying that the brand image, which refers to how customers perceive the brand, is not included. This study augments the limited body of knowledge regarding the internal corporate brandbuilding process in service firms. The aim, however, is not to generalise; instead, we hope to identify emerged issues that can be tested further. From a managerial perspective, this research provides business practitioners with examples of how service firms can handle the complexity of building a service brand. Moreover, this study attempts to provide some examples of how different conditions can influence corporate brand-building decisions along the way.

\section{INTERNAL BRAND BUILDING: A THEORETICAL REVIEW}

The corporate brand is a valuable strategic resource that can create a sustainable competitive advantage if managed properly. ${ }^{2,23}$ Among other advantages, a strong brand 
will favour the establishment of distribution networks, facilitate brand extensions and improve pricing flexibility. ${ }^{2}$ A corporate brand can be defined as 'a cluster of functional and emotional values, which promises stakeholders a particular experience'. ${ }^{26}$

\section{The internal brand-building process}

A structured approach to branding is proposed and the brand-building process is often described as a number of sequential stages. Based on a review of previous research, ${ }^{3-5,9,10,21,23,27,28}$ three key steps in the internal corporate brand-building process can be identified, that is, brand audit, brand identity and brand position statement. These three steps refer to the planning of the brand and occur before the brand is implemented, internally and/or externally. Although previous researchers describing the brand-building process are not consistent in their terminology or the exact number of stages involved, these three steps are commonly included.

The internal corporate brand-building process starts with a brand audit, 3,5,23 where internal and external factors are considered (Figure 1). The literature frequently discusses three internal factors, namely vision/mission, ${ }^{3,5,21}$ organisational culture $^{3,5,21,23}$ and brand architecture. $^{9,21,22,29,30}$ The brand audit also includes an analysis of external factors that influence the brand-building process. During this process, two main factors, or actors, should be considered, that is, customers and competitors. . $^{3,5,23,31}$ Other stakeholders could be included as a third factor, especially since the corporate brand is aimed at multiple stakeholders. ${ }^{3,20}$ The information gained from the brand audit enables the firm to understand the context in which the corporate brand is built.

The factors analysed in the brand audit will then influence the next step in the process, that is, brand identity. ${ }^{3,5,21,23}$ Brand identity is the central step of the brandbuilding process and is defined as how the firm wants the brand to be perceived. ${ }^{23}$ Brand identity consists of a core identity and an extended identity. ${ }^{23}$ The former represents the timeless essence of the brand, while the latter holds associations that add completeness to the brand. ${ }^{23}$ The central task is to manage the brand by creating meaningful associations. ${ }^{2}$ These associations can be related to a product, personality, the organisation or a symbol. ${ }^{23}$ Hence, in this study, brand personality is

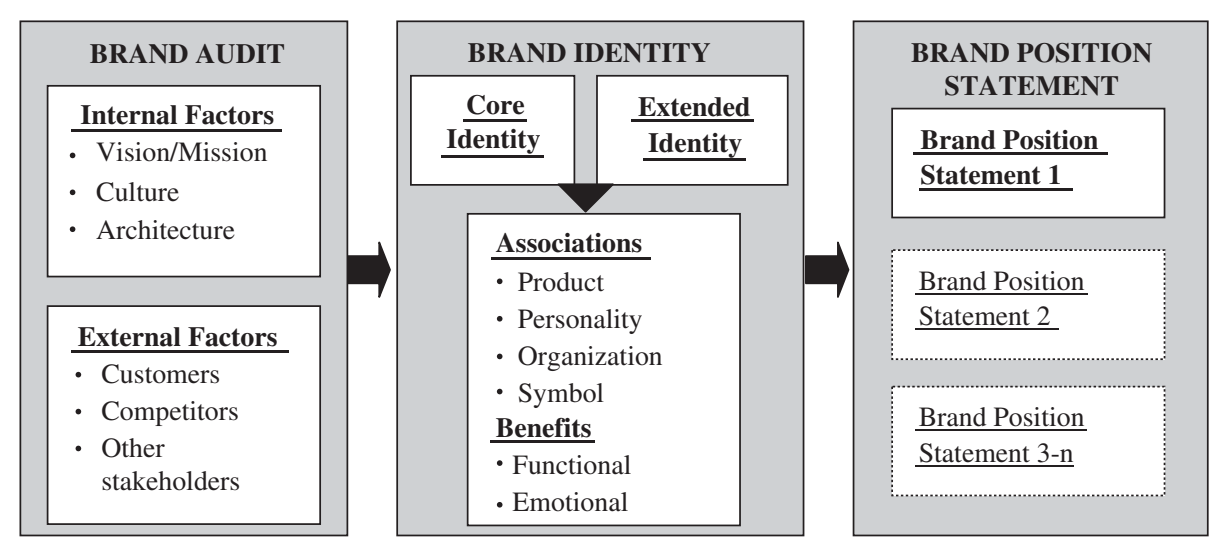

Figure I The internal corporate brand-building process: A conceptual framework 
handled as an integrated part of brand identity. The brand must also be able to deliver functional and emotional benefits to the customer, ${ }^{3,5,23}$ which should create value for the customer.

Finally, in the third stage, parts of brand identity are emphasised and chosen for active communication, that is, brand position statement(s). ${ }^{3,5,21,23}$ The brand position statement expresses how the corporate brand should be seen by external stakeholders and/or by employees. Several position statements may exist, but if more than one position statement is used it must not be contradictory. ${ }^{23,27}$ Moreover, according to Ries and Trout, ${ }^{31}$ a brand should have few associations/values. Figure 1 summarises the three stages included in the conceptual framework.

\section{METHODOLOGY}

The aim of this study was to explore the internal corporate brand-building process in Swedish service firms. Due to the lack of previous research in this area, ${ }^{32}$ a qualitative research approach and case studies were selected. In qualitative research, the purpose of sampling is often to gain access to relevant evidence about a phenomenon. A purposive sampling was applied in this study. The aim was not to generalise, but rather to find illustrative cases. The aim was to select firms that had initiated the brand-building process due to different circumstances. Swedish service firms with a strong corporate brand that had recently gone through the corporate brandbuilding process were reviewed as candidates, and three different cases were selected.

The first case, Skandia (SKA), is one of the world's leading suppliers of financial services, for example long-term savings and financial security solutions. In the autumn of 2003, SKA went through a crisis that impacted negatively on their corporate brand and they were, therefore, forced to restart their corporate brandbuilding process. The second case, Skandinaviska Enskilda Banken (SEB), was Sweden's first commercial bank, and today SEB is a strong corporate brand in the banking sector of northern and eastern Europe. SEB recently initiated a corporate brand-building process due to geographical expansion. Finally, the third case, Svensk Fastighetsförmedling (SFF), is the largest chain of real estate agents in Sweden with 202 agencies. During the past few years, SFF has made significant changes in their branding approach. The logo and slogan has been changed in an effort to homogenise and reposition its corporate brand.

Semi-structured personal interviews were used as the main data collection method in this study. An interview guide was developed based on the conceptual framework. To improve the validity, ${ }^{33}$ the interview guide was pre-tested on two managers. Besides interviews, company websites $^{34-36}$ and internal and external company documents ${ }^{37-40}$ were used to collect empirical data. In all three cases, the Marketing Manager was identified as the most knowledgeable person with respect to the internal corporate brandbuilding process and was, therefore, selected as the respondent for each company. Data reduction, data display and conclusion drawing $^{41}$ have been applied in the data analysis.

\section{RESULTS}

In accordance with previous research, 5,20 there was a common understanding across the cases that the corporate brand was a very important strategic asset. Previous research has stressed increasing interest in the corporate brand, and this was 
confirmed in all three cases. SKA and SEB explicitly stated that their aim was to create 'One SKA' and 'One SEB', indicating their desire to further consolidate the corporate brand. SFF wanted to homogenise the values in the corporate brand among all their real estate agencies. In addition, all respondents mentioned that the focus on corporate brand was not only specific to their company, but also something that was obvious for their industry as a whole.

In all three cases, the brand was viewed as a promise, which is a perspective scholars often use. ${ }^{8,10}$ Previous literature suggests that brands are especially important for service firms. ${ }^{15,12}$ The results of this study support this assertion, since all respondents perceived that the corporate brand enabled them to communicate both functional and emotional values to reduce the perceived risk as well as to add value for their customers and other stakeholders.

\section{The internal brand-building process}

Previous research proposes a structured approach to branding, ${ }^{21,23}$ and findings from this study show that all firms had a well-structured and documented branding process. All firms had recently started an internal corporate brand-building process and were now in the implementation phase. Based on a review of previous research, ${ }^{3-5,9,10,21,23,27}$ three key steps were identified in the internal corporate brandbuilding process, that is, brand audit, brand identity and brand position statement. Findings from this study support the three steps identified in the conceptual framework, although some minor differences exist (Figure 2).

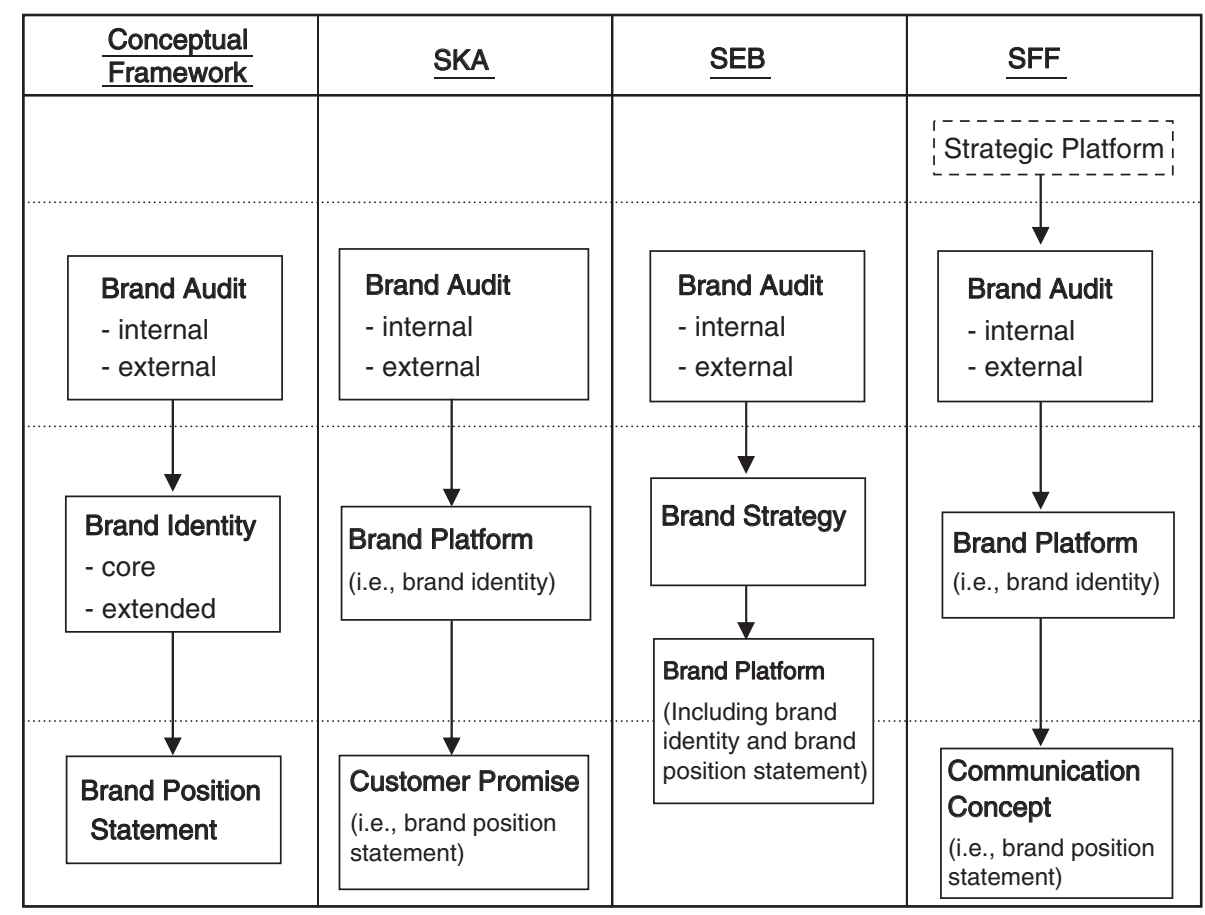

Figure 2 The internal corporate brand-building processes at SKA, SEB and SFF 


\section{Brand audit}

All firms were found to conduct a brand audit to understand the context in which the brand was being built. SFF, however, based their brand audit on a strategic platform that had been conducted before the internal corporate brand-building process began. The internal factors highlighted in the conceptual framework, that is, vision/ mission, ${ }^{3,5,23}$ organisational culture $3,5,21,23$ and brand architecture, ${ }^{9,21,22,29}$ were included in the brand audit in all three firms.

The vision/mission had a significant impact on the development of the corporate brand in all three cases. SFF particularly emphasised the importance of the organisational culture. In accordance with previous research, ${ }^{10} \mathrm{SFF}$ perceived that the most difficult challenge was to convince employees to communicate according to the brand. Both SKA and SEB highlighted problems related to brand architecture (ie how to manage the brand portfolio). They used a corporate brand combined with sub-brands, but their vision was to create 'one' master brand; both firms, therefore, considered abandoning some of their subbrands. For SKA, this created problems due to differences in the images between the corporate brand and one of the sub-brands. For SEB, the problem was to decide which sub-brands to keep. SEB tried to increase the number of values included in the corporate brand in order to include all subsidiaries.

With respect to external factors, both customers and competitors $3,5,23,31$ were included in the brand audit in all three cases. In SKA the changing buying behaviour of customers was an important issue, which created the question whether to keep separate sub-brands or consolidate these into one master brand. SEB was the firm that focused most on competitors. With respect to other stakeholders, SKA highlighted the importance of the general public, since their company's reputation had been severely damaged by its crisis.

Some additional factors were found to be included in the brand audit. SEB included both their latest business strategy and internal efficiency (ie the number of brands influences the cost efficiency and possibilities for cross-servicing). SFF included the business cycle in their brand audit since this heavily influences the buying behaviour of real estate. Finally, both SKA and SFF considered legislation as an additional external factor.

\section{Brand identity}

The next step in the corporate brandbuilding process is to determine the brand's identity. ${ }^{3,5,21,23}$ The identity clearly differed across cases. SKA used three core values in its core identity (innovative, competent and engaged) and was considering adding three additional values (simplicity, availability and a new way to offer financial services). SFF's core identity consisted of both old (Swedish, folksy and stable) and new values (fresh thinking, committed and personal simplifier), a total of six values. Meanwhile, SEB had 12 attributes describing its core identity (most evident; corporate, modern and competent) and an additional seven values included in its extended identity. No extended identity was identified at SKA or SFF, that is, associations that add texture and completeness to the corporate brand. In SEB emotional associations, such as open and vital, proactive and lively, joyful, exciting and close relations can be seen as their extended identity. Some similar attributes could be found among all three firms, that is, competence/professionalism and committed/engaged.

Interestingly, all firms had brand associations they wanted to remove from their 
identity. SKA wanted to remove the associations of being a scandalised company, SEB wanted to remove the associations of being formal, closed, cold and masculine and SFF wanted to remove the view of an old-fashioned personality. Approaches to removing these associations, however, varied across cases. SKA used the crisis to its advantage by communicating that, 'with our reputation, we cannot afford mistakes'. SEB added a number of emotional/ personality-related associations to offset its negative associations. Meanwhile, SFF completely changed its graphical profile and added four new brand values. It also developed a new brand position statement so it could be seen as a modern company.

In classifying the associations used for the core and extended identity, Aaker ${ }^{23}$ uses the perspectives of product, organisation, personality and symbol. Productrelated associations were not that evident across cases. Instead, associations connected to the organisation dominated in all cases, as suggested by Aaker, ${ }^{22}$ since the corporate brand, above all, represents the organisation. Moreover, all firms realised the importance of having personality-related associations. SKA, however, was unable to work with brand personality during the crisis. It needed to remove the associations of being a greedy and dishonest company and restore its reputation among stakeholders, before it would be worthwhile to communicate its brand personality.

Brands should deliver functional and emotional benefits to the customer. . $^{3,5,23}$ The functional benefits offered by the SKA brand were described as improving the customers' financial status and offering intelligent solutions. SEB's slogan, 'financially yours', implies that SEB offers its customers both functional and emotional value. In addition, another functional benefit is stated as SEB should be clear on what it offers customers. SFF also offers its customers functional benefits, since they aim to simplify the customers' situation. Emotional benefits were most evident for SKA, which wanted the customer to feel smarter when doing business with SKA.

\section{Brand position statement(s)}

The result of the first two stages in the internal corporate brand-building process leads to the development of brand position statement(s), ${ }^{3-5,9,10,21,23,27}$ which for the three cases are summarised in Table 1 . In all cases, the brand position statements were based on the brand identity, as suggested by Aaker. ${ }^{23}$ SKA's three brand position statements (ie 'The most engaged partner', 'Improved economy' and 'Safety through all phases of life') were concise and included both emotional and functional values. At the time, these brand position statements started to be introduced over different channels, such as the company's web page, the annual report and through press releases. In addition, SKA had earlier developed a temporary position statement to handle the crisis, that is, 'we can't afford mistakes and therefore

Table I Analysis of the brand position statement(s)

\begin{tabular}{ll}
\hline SKA 'The most engaged partner' \\
'Improved economy' \\
'Safety through all phases of life' \\
'we can't afford mistakes and therefore \\
we have to be the best at what we do' \\
(temporary) \\
SEB 'We speak to and from individuals' \\
'We are open with our competence' \\
'We are easy to contact-whenever, \\
wherever' \\
In summary: 'An individual, active and \\
developing bank relation-at the customer's \\
choice of time and place'. \\
'Financially yours' (slogan) \\
'From one situation to another' (slogan) \\
The keyword is situation, which is used in \\
creative ways
\end{tabular}




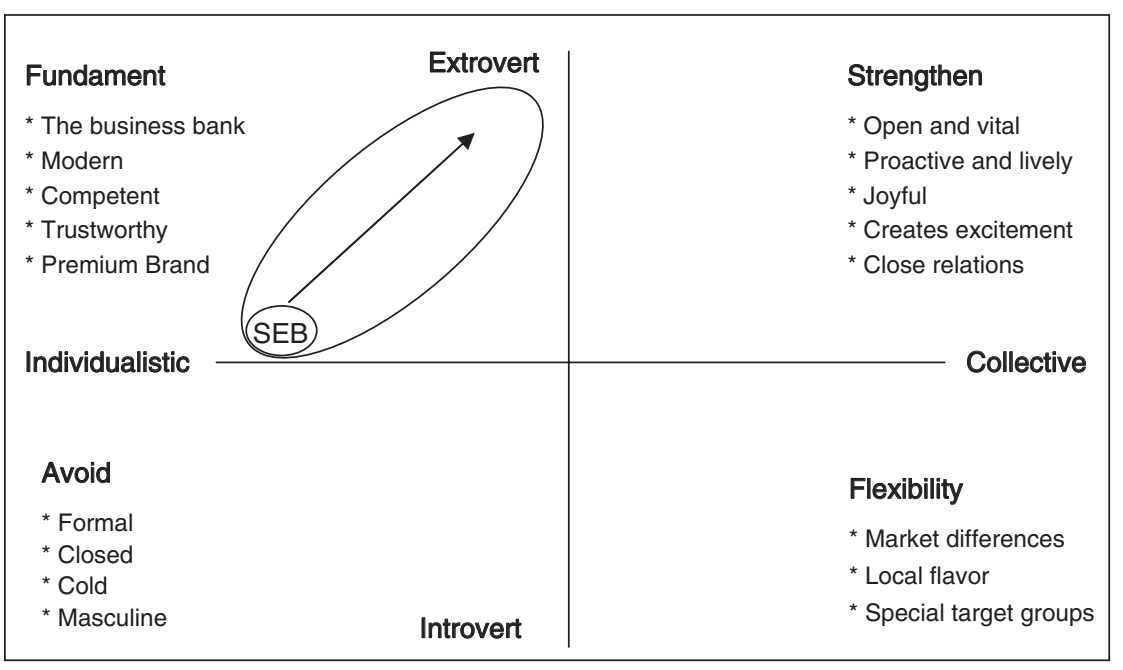

Figure 3 SEB's positioning

Source: Internal document at SEB, 2006

we have to be the best at what we do'. This statement is an example of how something negative can be converted into something positive.

SEB uses a concise brand position statement in its slogan, 'financially yours'. The company, however, aims to broaden its position to facilitate the inclusion of all international subsidiaries into the corporate brand, while maintaining its traditional foundation (see Figure 3). SEB's traditional foundation can be described as being a business bank, modern, competent, trustworthy and representing a premium brand. Today, SEB also wants to become more extrovert. To achieve this, the company wants to add brand associations (ie being open and vital, proactive and lively and joyful and exciting, while simultaneously establishing close relations). In addition, SEB wants to avoid being associated with the attributes of being formal, closed, cold and masculine. SEB's strategy to include so many values contradicts the recommendation made by Ries and Trout, ${ }^{31}$ who argue that position statements should be narrow and simple.
SFF had decided to use 'from one situation to another' as their brand position statement. The keyword 'situation' was selected to be used in different, creative ways with the intention of eventually owning this word in the minds of the customers. This way of working is consistent with Ries and Trout's ${ }^{31}$ recommendations.

\section{CONCLUSIONS}

In this study, we have highlighted issues which have emerged and which can be tested further. The three firms in the study had recently experienced an internal corporate brand-building process; however, each company had initiated this process for different reasons. Both similarities and differences were found across the cases. Increased interest in the corporate brand was confirmed in all three cases, and all the firms aimed to strengthen their corporate brand.

The three stages in the corporate brandbuilding process, that is, brand audit, brand identity and brand position statements, could be identified in all cases. Some 
differences, however, were found within each stage. The first case, SKA, provides an example of how a crisis can initiate and influence the corporate brand-building process. First, due to the company's tarnished reputation, there was a need to focus on other stakeholders in the brand audit. SKA wanted to apologise to the general public before it could communicate the company's strengths. They wanted the public to perceive them as a good company again. Customers generally were not leaving SKA because of the scandal, but the company was concerned they might do so if the public image of SKA remained negative. Moreover, SKA found it impossible to work with the brand personality during the crisis. Instead they had to remove any bad associations before they could start to communicate their brand personality. Finally, in their temporary brand position statement, SKA managed to turn the crisis into something positive.

SEB started its internal brand-building process because of geographical expansion. Because of this, the company had to focus particularly on competitors in their brand audit. SEB's aim was to strengthen their corporate brand. They, however, were aiming to expand the number of values in their brand identity to be able to include all subsidiaries. Like SKA, SEB also wanted to replace some associations, but its strategy was to add a number of emotional/ personality associations to offset the negative associations.

SFF had initiated the internal brandbuilding process because of the need for a strategic repositioning of the corporate brand. From this follows the fact that their brand audit was based on a strategic platform developed before the internal corporate brand-building process began. To succeed with their repositioning, SFF had developed a core identity consisting of a combination of old and new values. To remove some of the old associations, the company had changed its graphical profile and added four new brand values and a new brand position statement so it could be seen as a modern and vital company. It had selected a simple but vigorous positioning statement with one keyword with the aim of being remembered by its customers. SFF perceived that the most difficult challenge was to ensure that all employees would live by the new values and communicate according to the repositioned brand.

\section{MANAGERIAL IMPLICATIONS}

The value of a strong corporate brand has been highlighted, and it should be a prioritised area in all service firms. This study proves that building a corporate brand involves numerous difficult decisions, a company-wide approach, strong leadership and consistency. It is easy to underestimate the work needed to plan and execute a corporate brand.

This study gives managers indications related to special issues that need to be considered when a firm must respond to a scandal, geographical expansion or when there is a need to reposition a brand. If the brand is damaged, one strategy can be to develop a temporary brand position statement to overcome the crisis, and then communicate the new brand values. In the event of geographical expansion, decisions need to be made concerning brand architecture, and whether sub-brands should be kept or consolidated into one corporate brand. Making changes on several levels, with regard to brand values, logo and the position statement, can contribute significantly to the repositioning of a brand. The most difficult task, however, is to translate new brand values into the daily behaviours of employees. Finally, three 
different strategies to remove negative associations have been presented, that is, to turn something negative into positive, to add emotional/personality values and to simultaneously add new values, change logo and develop new brand position statement(s).

\section{SUGGESTIONS FOR FUTURE RESEARCH}

This study has highlighted some issues that need further qualitative or quantitative testing among larger populations. One suggestion is to create a larger sample of firms that have gone through the internal brand-building process due to different circumstances, to search for similarities and differences among the groups as well as across groups. Also, this study focused on the internal corporate brand-building process in service firms, that is, the planning phase of the process. Based on this, we suggest that for future research focus should be applied also to the implementation phase of the corporate brand-building process both internally and externally. Evidence from this study has revealed that the internal implementation of the brand was seen as a major challenge, especially in service firms. Finally, another area for future research would be to investigate the values of a strong corporate brand in service firms and how this affects performance.

\section{References}

(1) Keller, K. L. and Lehmann, D. (2003) 'How do brands create value?', Marketing Management, Vol. 12, No. 3, pp. 26-31.

(2) Kay, M. J. (2006) 'Strong brands and corporate brands', European Journal of Marketing, Vol. 40, No. 7/8, pp. 742-760.

(3) de Chernatony, L. (2001) 'From Brand Vision to Brand Evaluation', Butterworth-Heinemann, Oxford.

(4) Harris, F. and de Chernatony, L. (2001) 'Corporate branding and corporate brand performance', European Journal of Marketing, Vol. 35, pp. 441-456.
(5) Knox, S. and Bickerton, D. (2003) 'The six conventions of corporate branding', European Journal of Marketing, Vol. 37, pp. 998-1016.

(6) Leitch, S. and Richardson, N. (2003) 'Corporate branding in the new economy', European Journal of Marketing, Vol. 37, pp. 1065-1079.

(7) Balmer, J.M.T. and Greyser, S.A. (2006) 'Corporate marketing-Integrating corporate identity, corporate branding, corporate communications, corporate image and corporate reputation', European Journal of Marketing, Vol. 40, No. 7/8, pp. 730-741.

(8) Berry, L. (2000) 'Cultivating service brand equity', Journal of the Academy of Marketing Science, Vol. 28, pp. 128-137.

(9) Melin, F. (1999) 'Varumärkesstrategi', Författarna och Liber AB, Malmö.

(10) de Chernatony, L. and Segal-Horn, S. (2003) 'The criteria for successful services brands', European Journal of Marketing, Vol. 37, pp. 1095-1118.

(11) Banducci, B. and Keneally, B. (2001) 'Consumer services: The master brands of the twenty-first century', http://www.bcg.com/publications/files/ Master_Brands_Apr_01.pdf.

(12) Papasolomou, I. and Vrontis, D. (2006) 'Building corporate branding through internal marketing: The case of the UK retail bank industry', Journal of Product \& Brand Management' Vol. 15, No. 1, pp. 37-47.

(13) Pina, J. M., Martinez, E., de Chernatony, L. and Drury, S. (2006) 'The effects of service brand extensions on corporate image-An empirical model', European Journal of Marketing, Vol. 40, No. 1/2, pp. 174-197.

(14) Krishnan, B. and Hartline, M. (2001) 'Brand equity: Is it more important in services?' Journal of Services Marketing, Vol. 15, pp. 328-342.

(15) McDonald, M., de Chernatony, L. and Harris, F. (2001) 'Corporate marketing and service brands', European Journal of Marketing, Vol. 35, pp. 335-352.

(16) Einwiller, S. and Will, M. (2002) 'Towards an integrated approach to corporate branding-An empirical study', Corporate Communications, Vol. 7, pp. 100-109.

(17) Balmer, J.M.T. (1995) 'Corporate branding and connoisseurship', Journal of General Management, Vol. 21, No. 1, pp. 24-46.

(18) Bickerton, D. (2000) 'Corporate reputation versus corporate branding: The realist debate', Corporate Communications: An International Journal, Vol. 5, pp. $42-48$.

(19) Balmer, J.M.T. (2001) 'Corporate identity, corporate branding and corporate marketingSeeing through the fog', European Journal of Marketing, Vol. 35, pp. 248-291.

(20) Balmer, J.M.T. and Gray, E. (2003) 'Corporate brands: What are they? What of them?' European Journal of Marketing, Vol. 37, pp. 972-997. 
(21) Urde, M. (2003) 'Core value-based corporate brand building', European Journal of Marketing, Vol. 37, pp. 1017-1040.

(22) Aaker, D. (2004) 'Leveraging the corporate brand', California Management Review, Vol. 46,pp. 6-18.

(23) Aaker, D. (1996) 'Building Strong Brands', Simon \& Schuster UK Ltd, London.

(24) Daffey, A. and Abratt, R. (2002) 'Corporate branding in a banking environment', Corporate Communications: An International Journal, Vol. 7, pp. 87-91.

(25) Grace, D. and O'Cass, A. (2002) 'Brand associations: Looking through the eye of the beholder', Qualitative Market Research, Vol. 5, pp. 96-111.

(26) de Chernatony, L. (2002) 'Would a Brand Smell Any Sweeter by a Corporate Name?', Corporate Reputation Review, Vol. 5, No. 2/3, pp. 114-132.

(27) Keller, K. L. (2003) 'Strategic Brand Management, Building, Measuring, and Managing Brand Equity', 2nd ed, Prentice-Hall, New Jersey, Upper Saddle River.

(28) Karlsson, T. (2006) 'Internal corporate brand building', Licentiate Thesis, Luleå University of Technology, Luleå, 2006:68.

(29) Petromili, M., Morrison, D. and Million, M. (2002) 'Brand architecture: Building brand portfolio value', Strategy E Leadership, Vol. 30, pp. 22-28.
(30) Uggla, H. (2006) 'The corporate brand association base: A conceptual model for the creation of inclusive brand architecture', European Journal of Marketing, Vol. 40, No. 7/8, pp. 785-802.

(31) Ries, A. and Trout, J. (2001) 'Positioning, How to be Seen and Heard in the Overcrowded Marketplace', McGraw-Hill, New York.

(32) Marshall, C. and Rossman, G. B. (1999) 'Designing Qualitative Research', Sage Publications, Thousand Oaks.

(33) Yin, R. (2003) 'Case Study Research: Design and Methods', Sage Publications, Thousands Oaks.

(34) Skandia Homepage, http://www.skandia.se.

(35) SEB Homepage, http://www.seb.se.

(36) Svensk Fastighetsförmedling Homepage, http:// www.svenskfast.se.

(37) Skandia Annual Report, (2005). Printed in 2006.

(38) SEB Annual Report, (2005). Printed in 2006.

(39) SEB. (2006) Internal Document. 'Current situation \& road map', SEB's Market Communication, Q1-2006.

(40) Svensk Fastighetsförmedling. (2005) 'Från ett läge till ett annat', Internal Brand Manual.

(41) Miles, M. and Huberman, M. (1994) 'Qualitative Data Analysis', Sage Publications, Thousands Oaks. 